\title{
Analisis Literasi Sains Siswa Sekolah Dasar Pada Kasus Pandemi Covid-19
}

\author{
Andi Wibowo \\ Prodi PGSD FIP Universitas Islam Raden Rahmat Malang, Indonesia \\ andi21harto@gmail.com
}

\begin{abstract}
This study is motivated by the large number of school-age children infected with COVID-19. This study aims to determine the level of scientific literacy of elementary school students in the case of the Covid-19 pandemic. This research is a descriptive quantitative research. Research procedures in this study include (1) problem definition, (2) sample selection, (3) design of measurements \& instruments, (4) collect the data, (5) analyze the data, (6) report the results. The study population was elementary school students in Malang district. The sample of this research was 336 students from grade 1 to grade 6 elementary school. The data collection technique used interview and questionnaire techniques. The instruments used in this study were interview sheets and questionnaire sheets. The results showed that the level of scientific literacy of elementary school students was in the moderate to good category. However, the analysis of each indicator of elementary school students from grade 1 to grade 6 shows that in the attitude domain (1) interested in science and (2) environmental awareness and knowledge domain explaining scientific phenomena still shows a tendency in the sufficient category.
\end{abstract}

Keywords: analysis; scientific literacy; elementary school students; the case of the covid-19 pandemic.

\section{ABSTRAK}

Penelitian ini dilatarbelakangi oleh besarnya jumlah anak-anak usia sekolah yang terjangkit covid-19. Penelitian ini bertujuan untuk mengetahui tingkat literasi sains siswa sekolah dasar pada kasus pandemi covid-19. Penelitian ini merupakan penelitian kuantitatif deskriptif. Prosedur penelitian dalam penelitian ini meliputi (1) problem definition, (2) sample selection, (3) design of measurements \& instruments, (4) collect the data, (5) analyse the data, (6) report the results. Populasi penelitian adalah siswa sekolah dasar di kabupaten Malang. Sampel penelitian ini sebanyak 336 siswa dari kelas 1 sampai kelas 6 sekolah dasar. Teknik pengambilan data menggunakan teknik wawancara dan angket. Instrumen yang digunakan dalam penelitian ini adalah lembar wawancara dan lembar angket. Hasil penelitian menunjukkan bahwa tingkat literasi sains siswa sekolah dasar pada kategori cukup sampai baik. Namun, secara analisis tiap indikator siswa sekolah dasar dari kelas 1 sampai kelas 6 menunjukkan bahwa pada domain sikap (1) tertarik pada sains dan (2) kesadaran lingkungan dan domain pengetahuan menjelaskan fenomena secara ilmiah masih menunjukkan kecenderungan pada kategori cukup.

Kata Kunci: analisis; literasi sain; siswa sd; kasus pandemi covid-19.

Submitted May 21, 2021 | Revised Jun 12, 2021 | Accepted Jun 21, 2021

\section{Pendahuluan}

Literasi sains (scientific literacy) siswa Indonesia pada saat ini masih rendah. Hal ini dapat diketahui dari hasil studi dua lembaga internasional, studi nasional, maupun fenomena yang terjadi sehari-hari. Hasil Studi TIMSS (Trends in Mathematics and Science Study) tahun 2015 menunjukkan bahwa dimensi knowing, applying, reasoning, dan science practices siswa SD menempati urutan ke-44 dari 47 negara, sedangkan hasil studi PISA (Programme for International Student Assessment) tahun 2015 juga menunjukkan bahwa dimensi contexts, knowledge, competencies, dan attitudes menempati urutan ke 62 dari 69 negara. Beberapa studi nasional yang dilakukan oleh Aryani, dkk., (2016), Ardiansyah, dkk., (2016), Arohman, dkk., (2016), Nadhifatuzzahro, dkk., (2015), dan Odja \& Payu (2014) juga menunjukkan bahwa literasi sains siswa sampai saat ini masih rendah. Berbagai fenomena sehari-hari juga menunjukkan rendahnya tingkat literasi sains. Beberapa contoh berikut ini menunjukkan rendahnya dampak sains bagi perubahan pola perilaku kehidupan masyarakat Indonesia. Misalnya, pekerja papan reklame memperbaiki papan reklame tersebut dengan memanjat tiang listrik sehingga tersengat arus listrik tegangan tinggi. Penangkap belut menggunakan listrik tanpa alas kaki karet atau bahkan menceburkaan 
diri ke sungai sambil membawa alat penyetrum ikan tersebut. Orang merasa aman berteduh di bawah pohon rindang ketika hujan berpetir. Orang masih membuang sampah dan limbah ke sungai sehingga sungai tercemar dan dapat menjadi bencana banjir ketika hujan lebat. Orang tidak mencuci tangan sebelum makan sehingga dapat terjangkit panyakit yang disebabkan kuman penyakit. Pembangunan septitank berdekatan dengan sumur yang berakibat air sumur tercemar limbah. Masih banyak lagi contoh rendahnya literasi sains.

Peran literasi sains penting dalam menghadapi dinamika perubahan lingkungan dan masyarakat. Literasi sains dimaknai dengan istilah "melek sains". Literasi sains merupakan kemampuan mengaitkan isu-isu yang berhubungan dengan sains, dan dengan pemikiran-pemikiran sains, sebagai warga yang reflektif (OECD/PISA, 2015: 20). Literasi sains berimplikasi pada kemampuan seseorang mengidentifikasi isu-isu sains yang melandasi pengambilan keputusan lokal dan nasional yang dapat pula menunjukkan posisi sains dan teknologi yang telah diterimanya (Liliasari, 2011: 3-4). Literasi sains berperan dalam menyikapi keberadaan permasalahan yang berkaitan dengan sains. Hal tersebut berimplikasi pada dunia saat ini yang sedang dilanda pandemi covid-19.

Pada akhir tahun 2019 dan awal 2020 terdapat kasus infeksi virus covid-19. Infeksi ini telah merambah ke seluruh penjuru dunia hingga menjadi pandemi. Pandemi covid-19 ini, telah menjadi bencana nonalam di dunia ini. Jumlah penderita semakin hari semakin banyak baik penderita muda ataupun tua. Pada jenjang pendidikan di Indonesia, anak-anak usia sekolah (0-18 tahun) telah menyumbang 8,87\% kasus covid-19 secara nasional. Berdasarkan data tersebut, diketahui bahwa anak usia pendidikan sekolah dasar (7-12 tahun) menyumbang angka tertinggi sebanyak 29,8\% (Wibowo, 2021). Begitu banyaknya jumlah penderita covid-19 dikalangan anak-anak sekolah dasar maka perlu menilik kembali pembelajaran IPA di sekolah dasar.

Kesadaran akan literasi sains dalam kasus pandemi covid-19 sangat penting. Literasi sains menuntut seseorang untuk memiliki pengetahuan dalam memerikan (describe), menjelaskan, dan memprediksi fenomena alam salah satunya adalah pendemi covid-19. Seseorang yang memiliki literasi sains berarti mampu membaca dengan paham artikel-artikel tentang IPA. Pemahaman literasi sains membawa sesorang untuk selalu memiliki kapasitas dalam menggunakan pengetahuan ilmiah, mengidentifikasi pertanyaan-pertanyaan dan untuk menarik kesimpulan berdasarkan bukti-bukti agar dapat membantu dan membuat keputusan (Rustaman, 2011) misalnya berkenaan dengan kasus pandemi covid-19. Literasi sains akan membantu siswa dalam memahami pentingnya protokol kesehatan dan vaksinasi di masa pendemi yang sedang merebak saat ini. Ketua LPPM Unesa, Prof. Dr. Darni, M.Hum., menyatakan bahwa literasi sains merupakan pondasi yang sangat kuat untuk bersikap dan bertindak pada masa covid-19 (UNESA, 2020). Rahayu (2020) juga menegaskan bahwa mempromosikan literasi sains merupakan langkah penting untuk menjawab berbagai tantangan termasuk Covid-19 dan perubahan iklim. Begitu pentingnya literasi sains pada masa pandemi covid-19 maka penelitian ini akan menyelidiki tingkat kemampuan literasi sains siswa sekolah dasar pada kasus pandemi covid-19. Melalui penelitian ini diharapkan dapat memetakan kemampuan literasi sains siswa SD pada kasus pandemi covid-19. Pemetaan kemampuan literasi siswa dapat dijadikan referensi dan pertimbangan dalam strategi pelaksanaan pembelajaran tatap muka di sekolah.

\section{Metode Penelitian}

Penelitian ini menggunakan pendekatan deskriptif dan pendekatan kuantitatif. Prosedur penelitian meliputi (1) problem definition, (2) sample selection, (3) design of measurements \& instruments, (4) collect the data, (5) analyse the data, (6) report the results (Cohen, et al., 2018). Lokasi penelitian adalah sekolah dasar di kabupaten Malang. Waktu penelitian adalah dari 1 Desember 2020 sampai 31 Januari 2021. Populasi penelitian adalah siswa sekolah dasar di kabupaten Malang. Sampel penelitian ini sebanyak 336 siswa dari kelas 1 sampai kelas 6 sekolah dasar. Teknik pengambilan data menggunakan teknik wawancara dan angket. Instrumen yang digunakan dalam penelitian ini adalah lembar wawancara 
dan lembar angket. Teknik analisis data menggunakan teknik analisis data deskriptif dan persentase kemampuan literasi sains (Tabel 1).

Tabel 1. Persen kemampuan literasi sains

\begin{tabular}{ccc}
\hline Tingkat Penguasaan & Nilai Huruf & Kategori \\
\hline $86-100 \%$ & $\mathrm{~A}$ & Sangat Baik \\
$76-85 \%$ & $\mathrm{~B}$ & Baik \\
$60-75 \%$ & $\mathrm{C}$ & Cukup \\
$55-59 \%$ & $\mathrm{D}$ & Kurang \\
$\leq 54 \%$ & $\mathrm{E}$ & Sangat Kurang \\
\hline
\end{tabular}

(Purwanto, 2002)

\section{Hasil dan Pembahasan}

Penelitian ini merupakan penelitian deskriptif kuantitatif. Penelitian ini dilatarbelakangi oleh rendahnya literasi sains siswa di Indonesia dan banyaknya kasus infeksi covid-19 yang menjangkit anakanak usia pendidikan sekolah dasar. Populasi dala penelitian ini adalah siswa sekolah dasar di kabupaten Malang. Sampel penelitian ini adalah siswa sekolah dasar sebanyak 336 siswa mulai dari kelas 1 sampai kelas 6 SD. Data diambil melalui dua teknik yaitu wawancara dan angket. Instrumen yang digunakan adalah lembar angket dan lembar wawancara.

Pengukuran dilaksanakan untuk memetakan literasi sains siswa SD. Literasi sains masih menjadi tujuan utama dalam pembelajaran IPA. Literasi sains ini pada akhirnya akan berpengaruh kuat pada wawasan individu siswa (Lederman, et al., 2013: 138). Pemahaman terhadap hakikat IPA dan inkuiri ilmiah diharapkan dapat dikembangkan dalam kehidupan sehari-hari. Selain itu, Stefanova, et al., (2010: 114) menyarankan untuk menjadikan literasi sains sebagai program yang dicanangkan dalam kurikulum nasional. Pada kurikulum 2013, tahapan pembelajaran menggunakan pendekatan ilmiah meliputi mengobservasi, menanya, mencoba, mengasosiasi, dan mengkomunikasi. Implementasi pembelajaran inkuiri merupakan salah satu cara untuk mengembangkan literasi sains (Okada, 2013: 264). Hasil pengukuran kemampuan literasi sains dapat dilihat pada Tabel 2, Tabel 3, dan Tabel 4.

Tabel 2. Data kemampuan literasi sains siswa SD kelas bawah pada kasus Covid-19

\begin{tabular}{llccc}
\hline \multirow{2}{*}{ Domain } & \multicolumn{1}{c}{ Indikator } & \multicolumn{3}{c}{ Persentase Kemampuan (\%) } \\
& & Kelas 1 & Kelas 2 & Kelas 3 \\
\hline \multirow{2}{*}{ Sikap } & Tertarik pada sains & 62,72 & 64,73 & 64,96 \\
& Menghargai pendekatan inkuiri ilmiah & 76,56 & 78,79 & 81,25 \\
& Kesadaran lingkungan & 74,11 & 75,45 & 74,11 \\
\multirow{3}{*}{ Pengetahuan } & Menjelaskan fenomena secara ilmiah & 69,35 & 69.35 & 71,28 \\
& Merancang dan mengevaluasi inkuiri ilmiah & 88,10 & 90,33 & 89,58 \\
& Menginterpretasi data dan fakta-fakta secara ilmiah & 83,04 & 80,51 & 80,95 \\
\hline
\end{tabular}

Berdasarkan Tabel 2 dapat diketahui sebaran tingkat kemampuan literasi sains siswa sekolah dasar pada kelas bawah yaitu kelas 1, kelas 2, dan kelas 3. Berdasarkan data pada Tabel 2 dapat diketahui bahwa pada domain sikap tertarik pada sains dan kesadaran lingkungan, siswa SD kelas bawah masih dalam kategori cukup, sedangkan pada domain sikap menghargai pendekatan inkuiri ilmiah ada pada kategori baik. Pada domain pengetahuan dapat diketahui bahwa pada indikator menjelaskan fenomena secara ilmiah masih berada pada kategori cukup. Pada indikator merncang dan mengevaluasi inkuiri ilmiah pada kategori sangat baik. Pada indikator menginterpretasikan data dan fakta-fakta secara ilmiah masih dalam kategori baik. 
Wibowo, Analisis literasi sains siswa sekolah dasar...

Tabel 3. Data kemampuan literasi sains siswa SD kelas atas pada kasus Covid-19

\begin{tabular}{|c|c|c|c|c|}
\hline \multirow{2}{*}{ Domain } & \multirow{2}{*}{ Indikator } & \multicolumn{3}{|c|}{ Persentase Kemampuan (\%) } \\
\hline & & Kelas 4 & Kelas 5 & Kelas 6 \\
\hline \multirow[t]{3}{*}{ Sikap } & Tertarik pada sains & 69,20 & 71,43 & 71,43 \\
\hline & Menghargai pendekatan inkuiri ilmiah & 81,03 & 83,71 & 85,04 \\
\hline & Kesadaran lingkungan & 74,55 & 79,02 & 77,01 \\
\hline \multirow[t]{3}{*}{ Pengetahuan } & Menjelaskan fenomena secara ilmiah & 67,86 & 69,05 & 69,79 \\
\hline & Merancang dan mengevaluasi inkuiri ilmiah & 88,99 & 92,26 & 91,67 \\
\hline & Menginterpretasi data dan fakta-fakta secara ilmiah & 79,02 & 84,08 & 81,85 \\
\hline
\end{tabular}

Berdasarkan Tabel 3 dapat diketahui sebaran tingkat kemampuan literasi sains siswa sekolah dasar pada kelas atas yaitu kelas 4, kelas 5, dan kelas 6. Berdasarkan data pada Tabel 3 dapat diketahui bahwa pada domain sikap tertarik pada sains dan kesadaran lingkungan, siswa SD kelas atas masih dalam kategori cukup, sedangkan pada domain sikap menghargai pendekatan inkuiri ilmiah ada pada kategori baik. Pada domain pengetahuan dapat diketahui bahwa pada indikator menjelaskan fenomena secara ilmiah masih berada pada kategori cukup. Pada indikator merncang dan mengevaluasi inkuiri ilmiah pada kategori sangat baik. Pada indikator menginterpretasikan data dan fakta-fakta secara ilmiah masih dalam kategori baik.

Tabel 4. Rekapitulasi data kemampuan literasi sains siswa SD pada kasus Covid-19

\begin{tabular}{lcccccc}
\hline \multirow{2}{*}{ Domain } & \multicolumn{3}{c}{ Persentase Kemampuan (\%) } \\
& Kelas 1 & Kelas 2 & Kelas 3 & Kelas 4 & Kelas 5 & Kelas 6 \\
\hline Sikap & 71,13 & 72,99 & 73,44 & 74,93 & 78,05 & 77,83 \\
Pengetahuan & 80,16 & 80,06 & 80,61 & 78,62 & 81,80 & 81,10 \\
Rata-Rata Kemampuan Literasi Sains & 75,64 & 76,53 & 77,02 & 76,77 & 79,92 & 79,46 \\
\hline
\end{tabular}

Berdasarkan Tabel 4 dapat diketahui sebaran kemampuan literasi sains siswa SD pada msingmasing domain dan secara keseluruhan. Berdasarkan Tabel 4 diketahui bahwa pada domain sikap, siswa kelas 1, 2, 3, dan 4 masih berada pada kategori cukup, sedangkan pada kelas 5 dan kelas 6 pada kategori baik. Pada domain pengetahuan secara keseluruhan berada pada kategori baik. Secara rata-rata kemampuan literasi sains siswa SD berada pada tingkat kemampuan baik, namun siswa kelas 1 masih berada pada tingkat kemampuan cukup.

\section{Kesimpulan}

Berdasarkan hasil penelitian maka dapat diketahui bahwa tingkat literasi sains siswa sekolah dasar pada kategori cukup sampai baik. Namun, secara analisis tiap indikator siswa sekolah dasar dari kelas 1 sampai kelas 6 menunjukkan bahwa pada domain sikap (1) tertarik pada sains dan (2) kesadaran lingkungan dan domain pengetahuan menjelaskan fenomena secara ilmiah masih menunjukkan kecenderungan pada kategori cukup.

\section{Daftar Pustaka}

Ardiansyah, A.A.I., Irwandi, D., \& Murniati, D. (2016). Analisis Literasi Sains Siswa Kelas XI IPA Pada Materi Hukum Dasar Kimia di Jakarta Selatan. Jurnal EduChemia Jurnal Kimia \& Kependidikan). 1 (2): 149-161.

Arohman, M., Saefudin, Priyandoko, D. (2016). Kemampuan Literasi Sains Siswa Pada Pembelajaran Ekosistem. Proceeding Biology Education. 13 (1): 90-92.

Aryani, A.K., Suwono, H., \& Parno. (2016). Profil Kemampuan Literasi Sains Siswa SMPN 3 Batu. Jurnal Seminar Pendidikan IPA UM. 1: 847-855. 
Cohen, L., Manion, L., \& Morrison, K. (2018). Research Methods in Education. New York: Routledge Taylor \& Francis Group.

Lederman, N.G., Lederman, J.S., \& Antink, A. (2013). Nature of science and scientific inquiry as contexts for the learning of science and achievement of scientific literacy. International Journal of Education in Mathematics, Science and Technology, 1 (3), 138-147.

Liliasari. (2011). Pendidikan IPA Terintegrasi untuk Membangun Karakter Manusia Indonesia. Makalah disajikan dalam Seminar Nasional Pendidikan IPA, FMIPA, UNY, 24 September.

Nadhifatuzzahro, D., Setiawan, B., \& Sudibyo, E. (2015). Kemampuan Literasi Sains Siswa Kelas VII-B SMP Negeri 1 Sumobito Melalui Pembuatan Jamu Tradisional. Makalah disajikan pada Seminar Nasional Fisika dan Pembelajarannya Universitas Negeri Malang.

Odja, A.H., \& Payu, C.S. (2014). Analisis Kemampuan Awal Literasi Sains Siswa Pada Konsep IPA. Makalah disajikan pada Seminar Nasional Kimia, Jurusan Kimia, FMIPA, Universitas Negeri Surabaya, 20 September.

OECD/PISA. (2015). PIS A 2015 Assessment Framework. Paris: OECD Publising.

Okada, A. (2013). Scientific Literacy in the Digital Age: Tools, Environments and Resources for CoInquiry. European Scientific Journal, 4: 263-274.

Purwanto, N. (2002). Prinsip-Prinsip dan Teknik Evaluasi Pengajaran. Bandung: PT Remaja Rosdakarya.

Rahayu, E.M. (2020). Literasi Sains Penting dalam Penanganan Covid-19. Diakses pada tanggal 12 Juni 2021, dari: https://www.republika.co.id/berita/qlf2hy52108740221000/literasi-sainspenting-dalam-penanganan-covid19.

Rustaman, N. (2011). Materi dan Pembelajaran IPA SD. Jakarta: Universitas Terbuka.

Stefanova, Y., Minevska, M., \& Evtimova, S. 2010. Scientific Literacy: Problems of Science Education in Bulgarian School. Problems of Education in the 21st Century, 19 (1): 1-12.

UNESA. (2020). Numerasi dan Literasi Sains, Jadi Pondasi Kuat di Masa Pandemi Covid-19. Diakses pada tanggal 12 Juni 2021, dari: https://www.unesa.ac.id/numerasi-dan-literasi-sains-jadi-pondasikuat-di-masa-pandemi-covid-19.

Wibowo, E. A. (2021). Satgas Sebut Anak Sekolah Menyumbang 8,8 Persen Kasus Covid-19 Nasional. Antara News. Diakses pada tanggal 22 Februari 2021, dari: https://nasional.tempo.co/read/14211 20/satgas-sebut-anak-sekolah-menyumbang-88-persen-kasus-covid-19nasional $/$ full\&view $=$ ok. 